\title{
THROUGH THE LOOKING GLASS: \\ IMPLICATIONS OF CANADA-UNITED STATES TRANSGOVERNMENTAL NETWORKS FOR DEMOCRATIC THEORY, INTERNATIONAL LAW, AND THE FUTURE OF NORTH AMERICAN GOVERNANCE
}

\author{
KATHRYN BRYK FRIEDMAN*
}

Viewing international law through the lens of transgovernmental networks offers a unique perspective to investigating the connection between democracy and international law. By applying the concept of the "disaggregated state," the author evaluates the character and nature of transgovernmental networks within North America and offers suggestions for policymakers and scholars envisioning future models of North American governance.
Le fait de regarder le droit international à travers une lentille de réseaux transgouvernementaux procure une perspective unique pour examiner le lien entre démocratie et droit international. En appliquant le concept «d'État désagrégé,» l'auteur évalue le caractère et la nature des réseaux transgouvernementaux en Amérique du Nord et propose des suggestions aux décideurs et érudits en envisageant des modèles futurs de gouvernance nord-américaine.

\section{TABLE OF CONTENTS}

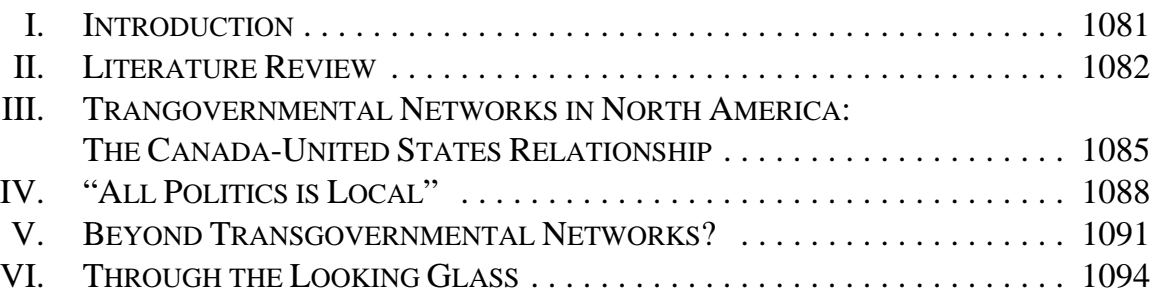

If I had a world of my own, everything would be nonsense. ${ }^{1}$

\section{INTRODUCTION}

In exploring the relationship between democratic theory and international law, many of the articles in this special volume focus on traditional international law mechanisms, such as treaties, agreements, and international organizations. ${ }^{2}$ This article uses an alternative lens — transgovernmental networks - to investigate the connection between democracy and international law. It explores the character and nature of transgovernmentalism in North America by applying Anne-Marie Slaughter's concept of the "disaggregated state"3 to the Canada-United States relationship. Part I provides a brief literature review of

Ph.D. (Political Science), J.D.; Deputy Director and Director of Research, University at Buffalo Regional Institute, School of Law; Adjunct Professor, University at Buffalo School of Law.

Alice in Wonderland, DVD (California: Walt Disney Pictures, 1951).

See e.g. Jeremy Farrall, “Does the UN Security Council Compound the Global Democratic Deficit?” (2009) 46 Alta. L. Rev. 913; Paul Martin, "Chávez, The Organization of American States, and Democracy in International Law” (2009) 46 Alta. L. Rev. 933; Kelisiana Thynne, “The International Criminal Court: A Failure of International Justice for Victims?” (2009) 46 Alta. L. Rev. 957; Andrew D. Mitchell \& Elizabeth Sheargold, “Global Governance: The World Trade Organization's Contribution” (2009) 46 Alta. L. Rev. 1061.

3 As explained below, this article uses the concept of the disaggregated state as set forth in Anne-Marie Slaughter, A New World Order (Princeton: Princeton University Press, 2004). 
transgovernmental networks; Parts II through V set forth empirical evidence collected from several sources cataloguing and describing these networks; and Part VI offers implications of these networks to democratic theory and international law, as well as to visioning future models of North American governance.

By employing this alternative lens and venturing through the looking glass, an undeniable, though curious logic to Canada-U.S. relations becomes apparent with threefold implications concerning transgovernmental network theory; the debate concerning democratic accountability and international law; and North American governance. First, analysis suggests that the concept of the disaggregated state is useful, but incomplete in explaining international co-operation between Canada and the U.S. Specifically, defining horizontal networks at the federal government level only and vertical networks as existing between federal government officials and supranational entities fails to capture the depth of the myriad of existing transgovernmental networks embodied at the state/provincial, regional, and local levels that exert influence on North American policy-making. This article therefore concludes that Slaughter's definition is too limiting and proposes suggestions for refining the concept of the disaggregated state. Second, transgovernmental networks that characterize the Canada-U.S. relationship are arguably more democratic than traditional international law mechanisms because of their decentralized nature and inclusion of private sector and nongovernmental organizations. Hence, at first glance, concerns about accountability and transparency seemingly become moot with evidence of the myriad of broad and cross-sector participation in North American transgovernmental networks. Nonetheless, the debate concerning the democratic deficit is turned on its head, with networks, like their traditional counterparts, raising fundamental questions regarding democratic accountability in international law. Third, the conclusion suggests that transgovernmental networks offer an alternative blueprint for North American governance in the interdependent, globalized world of the twenty-first century.

\section{LITERATURE REVIEW}

The following literature review is not meant to serve as an exhaustive treatment of the role of transnational networks in academic discourse. Rather, it provides a general sense as to concepts and frameworks of particular relevance when thinking of transnational networks in North America.

Although not a recent phenomenon, ${ }^{4}$ transnational networks have exploded onto the scene and multiplied in recent years. This can be attributed to a number of trends in the international system, such as enhanced economic integration, strengthened breadth and depth of technological information exchange, and increased globalization. As a result, transgovernmental networks have become objects of inquiry in academic circles.

Regardless of the field, scholars of transnational networks reject a reified concept of the nation-state, suggesting instead that international relations are far more complex. For example, in responding to the overemphasis of the importance of formal international

$4 \quad$ See Kal Raustiala, “The Architecture of International Cooperation: Transgovernmental Networks and the Future of International Law” (2002) 43 Va. J. Int'l L. 1 at 11-12. 
organizations and nation-states in international affairs, political scientists have defined transnational relations as "sets of direct interactions among sub-units of different governments that are not controlled or closely guided by the policies of the cabinets or chief executives of those governments." 5

This sub-state focus has found its way, too, into international legal scholarship. Whereas traditional international law scholars focus on the role of formal institutions and formal international legal norms in global governance, a more recent brand of international law scholarship exists that goes beyond this emphasis. Coined "transnational law," this research sweeps all domestic law bearing on international relations and law regulating relations between governments and foreign nations into the embrace of international law. ${ }^{6}$

As first - and perhaps best - conceptualized in a series of lectures by Philip Jessup at Yale Law School in 1956, ${ }^{7}$ transnational law includes all law that regulates actions or events that transcend national frontiers. In examining the inescapable problem of people everywhere whose "lives are affected by rules," Jessup pointed to the increasing complexity and dispersion of legal orders, norm-producing institutions, and legal actors that govern our lives. He argued that domestic and international law are not mutually exclusive; rather, there is an inseparability of the issues that underlie these legal regimes. Hence, Jessup offered a fresh approach to thinking about international law by pointing to the myriad of forms of subnation-state cross-border relations among state and non-state actors. ${ }^{8}$

Jessup's concepts continue to resonate in the globalized world of the twenty-first century. Most pertinently, scholars use the transnational law framework to examine transgovernmental networks, that is, networks of government officials exchanging information, coordinating policies, and working together to address common problems. ${ }^{9}$ Drawing implicitly on the work of Jessup, these scholars suggest that international law is not merely concerned with international organizations and the relationships among unitary state

Robert O. Keohane \& Joseph S. Nye, “Transgovernmental Relations and International Organizations” (1974) 27 World Politics 39 at 43; Joseph S. Nye, Jr. \& Robert O. Keohane, "Transnational Relations and World Politics: An Introduction” (1971) 25 International Organization 329. An early academic study of these relations between Canada and the U.S. was conducted by Annette Baker Fox, Alfred O. Hero, Jr. \& Joseph S. Nye, Jr., eds., Canada and the United States: Transnational and Transgovernmental Relations (New York: Columbia University Press, 1976).

$6 \quad$ See Peter Zumbansen, “Transnational Law” in Jan M. Smits, ed., Elgar Encyclopedia of Comparative Law (Cheltenham: Edward Elgar, 2006).

Philip C. Jessup, Transnational Law (New Haven: Yale University Press, 1956).

Ibid. at 8.

Anne-Marie Slaughter, "Global Government Networks, Global Information Agencies, and Disaggregated Democracy” (2003) 24 Mich. J. Int'l L. 1041; see also Sol Picciotto, “Networks in International Economic Integration: Fragmented States and the Dilemmas of Neo-Liberalism” (1997) 17 Nw. J. Int'l L. \& Bus. 1014; Sol Picciotto, "Fragmented States and International Rules of Law" (1997) 6 Soc. \& Leg. Stud. 259; Scott H. Jacobs, "Regulatory Co-operation for an Interdependent World: Issues for Government" in Organisation for Economic Co-operation and Development, ed., Regulatory Co-operation for an Interdependent World (Paris: Organisation for Economic Co-operation and Development, 1994); Anne-Marie Slaughter, "Governing the Global Economy through Government Networks" in Michael Byers, ed., The Role of Law in International Politics: Essays in International Relations and International Law (New York: Oxford University Press, 2000) 177 [Slaughter, "Governing the Global Economy"]. 
actors. Instead, international law takes into account the wide array of interconnections formed by sub-components of nation-states.

Slaughter recently examined transgovernmental networks as mechanisms or tools of governance in the global order. ${ }^{10}$ Coined the "disaggregated state," her focus is on the

\begin{abstract}
rising need for and capacity of different domestic government institutions to engage in activities beyond their borders, often with their foreign counterparts. It is regulators pursuing the subjects of their regulations across borders; judges negotiating minitreaties with their foreign brethren to resolve complex transnational cases; and legislators consulting on the best ways to frame and pass legislation affecting human rights or the environment. $^{11}$
\end{abstract}

The fundamental assumption of this body of work is that the concept of unitary and functionally identical rational state actors interacting above the level of the nation-state is "deeply artificial and ultimately counterproductive."12 Emphasizing the growing importance of these transgovernmental networks, she contends that the most important actors in world politics are no longer foreign ministries and heads of state, but rather, the same types of institutions essential to domestic politics, such as the courts and legislatures. ${ }^{13}$ Slaughter urges readers to lose their "conceptual blind spot” and see how the global policy-making really works:

\footnotetext{
Stop imagining the international system as a system of states - unitary entities like billiard balls or black boxes — subject to rules created by international institutions that are apart from, “above” these states. Start thinking about a world of governments, with all the different institutions that perform the basic functions of governments - legislation, adjudication, implementation — interacting both with each other domestically and also with their foreign and supranational counterparts. States still exist in this world; indeed, they are crucial actors. But they are "disaggregated.” They relate to each other not only through the Foreign Office, but also through regulatory, judicial, and legislative channels. ${ }^{14}$
}

Slaughter argues that the increasing number of governmental networks constitute "a pattern of regular and purposive relations among like government units working across the borders that divide countries from one another and that demarcate the 'domestic' from the 'international' sphere." 15 Networks, she says, are the solution to the "globalization paradox": the world needs global governance to combat problems that transcend borders (for example, crime and environmental degradation), however, most people fear the idea of a centralized, all-powerful world government.

Slaughter uses concepts of horizontal and vertical networks to support her thesis. Horizontal networks link counterpart officials across borders, for example, police

\title{
$10 \quad$ Slaughter, supra note 3.
}

$11 \quad$ Ibid. at 12.

12 Anne-Marie Slaughter, Andrew S. Tulumello \& Stepan Wood, "International Law and International Relations Theory: A New Generation of Interdisciplinary Scholarship” (1998) A.J.I.L. 367 at 384; see also Anne-Marie Slaughter, “The Real New World Order” (1997) 75:5 Foreign Affairs 183.

13 Slaughter, “Governing the Global Economy,” supra note 9.

$14 \quad$ Slaughter, supra note 3 at 5.

$15 \quad$ Ibid. at 14. 
investigators or financial regulators. ${ }^{16}$ These networks function as information networks (the flow of information and ideas, exchange of best practices, technical assistance, and training programs), enforcement networks (fostering co-operation to implement laws), and harmonization networks (establishing international standards and adjusting national laws to conform to them). Vertical networks are relationships between a nation's officials and a supranational organization. According to Slaughter, vertical networks, while more difficult to find in global governance, have a crucial role to play because, in some circumstances, states choose to delegate their individual governing authority to a "higher" entity. These networks, too, can be information, enforcement, or harmonization networks.

Slaughter provides an empirical foundation for her framework by cataloguing a world in which government officials - police investigators, financial regulators, judges, and legislators - exchange information and coordinate activity across national borders to tackle crime, terrorism, and the routine daily grind of international interactions. Slaughter argues that these networks make things happen in the world of international politics and policy. The modern global policy world, then, consists of states whose component parts are as important as their central leadership.

In addition to being descriptive, her work is prescriptive in that she argues that strengthening existing networks and developing new ones "could create a genuine global rule of law without centralized global institutions." 17 Transgovernmental networks present advantages that traditional forms of governance do not. Slaughter writes that a fundamental advantage of these networks is that they present possibilities to solve global problems in a manner that does not necessitate concentrating power in the international organizations, which are vulnerable to abuse. ${ }^{18}$ These networks also have the advantage of fostering experimentation and innovation, and dispensing the "time-consuming formality of traditional international organizations." ${ }^{19}$ Both Slaughter and Kal Raustiala articulate the inherent advantages transgovernmental networks have regarding protection and efficiency over international organizations, nonetheless, they also believe that these networks can improve compliance with international law. $^{20}$ In the end, these scholars contend that transgovernmental networks contribute to the new world order by "increasing the scope, nature, and quality of international cooperation."21

\section{TRANSGOVERNMENTAL NETWORKS IN NORTH-AMERICA: THE CANADA-UNITED STATES RELATIONSHIP}

Slaughter's work is insightful in that it demonstrates that national government networks are a critical part of the international legal order. This section applies Slaughter's concept of

Ibid. at 19.

Ibid. at 261.

Ibid. at 8-11.

Raustiala, supra note 4 at 24.

Ibid. at 76-83; see also Slaughter, supra note 3 at 183-86. This is an idea that also resonates with Keohane and Nye, supra note 5, who explored how transgovernmental relations furthered international organization and how transgovernmental relations were integral to the power of international organizations. According to these scholars, international organizations nourish and enhance transgovernmentalism, therefore, they have a central role in the future of world politics. 
the "disaggregated state" to North America. North America provides fertile ground for exploring transgovernmental relations because the characterization of North American integration as occurring from "the bottom-up" is well-documented. ${ }^{22}$ Contrary to supranational “top-down” models, such as the European Union with its myriad of institutions and structures above the nation-state, North American integration has occurred in the absence of strong institutions and structures. In fact, the North American Free Trade Agreement Between the Government of Canada, the Government of the United Mexican States and the Government of the United States of America ${ }^{23}$ was set up deliberately with weak institutions, reflecting long-standing concerns about ceding sovereignty to supranational institutions.

Within this complex North American web, the Canada-U.S. relationship has long been defined by networks and linkages. Although some of these linkages are a century old or more, such as the International Joint Commission, the vast majority are a relatively recent phenomena. They exploded onto the contemporary scene with the signing of the Canada-U.S. Free Trade Agreement in the late 1980s and the NAFTA in the early 1990s, both of which have ushered in opportunities for broadening and deepening collaborative efforts among the parties across sectors.

A microcosm of Slaughter's disaggregated world, Canada-U.S. relations are replete with transnational networks that play an important role in shaping the contours of North American integration. ${ }^{24}$ Empirical data suggests that well over 270 transgovernmental networks

22 See e.g. Stephen Blank, Stephanie R. Golob \& Guy Stanley, "SPP and the Way Forward for North American Integration: North American Solutions” (Paper presented to the International Studies Association (ISA), San Diego, March 2006) at 7, online: ISA <http://convention2.allacademic.com/ one/isa/isa06/index.php>; Susan E. Clarke \& Erica Chenoweth, "The Politics of Vulnerability: Constructing Local Performance Regimes for Homeland Security” (2006) 23 Review of Policy Research 95; Policy Research Initiative, Working Paper Series, WP009, “A Survey of Major Cross-Border Organizations Between Canada and the United States” by Jean-François Abgrall (Ottawa: Policy Research Initiative, 2005); Earl Fry, "The Role of Subnational Governments in North American Integration” in Thomas J. Courchene, Donald J. Savoie \& Daniel Schwanen, eds., The Art of the State II: Thinking North America (Montreal: Institute for Research on Public Policy, 2005); Susan E. Clarke, "Spatial Concepts and Cross-Border Governance Strategies: Comparing North American and Northern Europe Experiences" (Paper presented at the EURA Conference on Urban and Spatial European Policies, Turin, Italy, 18-20 April 2002), online: Dongbei University of Finance and Economics $<$ http://time.dufe.edu.cn/jingjiwencong/waiwenziliao/9clarke.pdf>; Gerardo Otero, "Mexico’s Political Future(s) in a Globalizing World Economy” (1995) 32 Canadian Review of Sociology and Anthropology 315.

2317 December 1992, Can. T.S. 1994 No. 2 (entered into force 1 January 1994) [NAFTA].

24 The Canadian government has conducted extensive empirical research documenting Canada-U.S. networks: see Canada School of Public Service, Advancing Canadian Interests in the United States: A Practical Guide for Canadian Public Officials by Jeff Heynen \& John Higginbotham (Ottawa: Canada School of Public Service, 2004); Canada School of Public Service, Building Cross-Border Links: A Compendium of Canada-US Government Collaboration by Dieudonné Mouafo, Nadia Ponce Morales \& Jeff Heynen, eds. (Ottawa: Canada School of Public Service, 2004). The methodology for the study consisted of a literature review; survey of approximately 70 federal, provincial, and territorial departments and agencies detailing institutions and agreements in place with U.S. counterparts; identification and analysis of case studies submitted by federal and provincial departments and agencies; approximately 30 senior-level interviews with federal and provincial deputy ministers, assistant deputy ministers, former ambassadors, parliamentarians, and private sector officials; federal working-level focus groups in three sectoral clusters; site visits to three provincial capitals (Edmonton, Toronto, and Halifax); and a workshop on the importance of the U.S. Department of Homeland Security on Canadian departments and agencies: see Heynen \& Higginbotham at 12. See also Policy Research Initiative, The 
between Canada and the U.S. exist across federal government sectors. ${ }^{25}$ These networks are not limited to those traditionally relegated to international affairs, such as trade, security, defence, foreign affairs, and immigration. They cut across every conceivable functional area, such as agriculture, finance, public safety, transportation, justice, energy, and the environment. The multitude of these channels can be organized loosely into three main categories: bilateral processes, ${ }^{26}$ bilateral agreements, ${ }^{27}$ and multilateral channels. ${ }^{28}$ Informal channels exist as well, with the Canadian government suggesting that these informal relations are a unique strength of the Canada-U.S. relationship. ${ }^{29}$ The latter relationships maintain a high degree of social capital, focused upon areas such as information sharing, joint problem solving, and joint operations. ${ }^{30}$

Environment networks nicely illustrate the breadth and depth of transgovernmental linkages that define the Canada-U.S. relationship. Approximately 50 bilateral arrangements exist that represent transboundary issues such as climate change, weather, wildlife, and waste. ${ }^{31}$ According to the Canadian government, Environment Canada deals with a number of U.S. departments and organizations on a formal and informal basis, with primary relationships established with the Environmental Protection Agency (EPA), the Department of Interior, the Department of Commerce, the Department of State, and the National Aeronautics and Space Administration. ${ }^{32}$

A broad array of agreements are part of the Canada-U.S. environmental network. One example is the 1996 Four Corners Agreement. This agreement, between Environment Canada and the EPA, is a bilateral administrative arrangement between the two governments and the chemical industry in both countries that involves the management of "new substances." Participants meet in person once a year and communicate regularly by e-mail and teleconference. ${ }^{33}$ Another example is the 2003 Ice Service Annex, ${ }^{34}$ which encourages the national weather agencies to seek collaborative or common solutions to collect, process,

Emergence of Cross-Border Regions between Canada and the United States: Roundtables Synthesis Report (Canada: Policy Research Initiative, 2006); Policy Research Initiative, The Emergence of CrossBorder Regions: Interim Report (Canada: Policy Research Initiative, 2005); Abgrall, supra note 22. According to the Heynen \& Higginbotham, ibid. at 10-12, this number represents the most significant linkages.

These bilateral processes are akin to Slaughter's information networks and consist primarily of advisory groups, commissions, coalitions, exchanges of personnel, forums, joint boards or panels; joint operations; joint programs; joint training; meetings of legislators; minister-secretary meetings; panels; summits; symposia; task forces; and working groups (ibid. at 22).

Bilateral agreements include treaties; protocols; memoranda of understanding; exchange of letters/notes; and mutual recognition agreements (ibid. at 24).

The most important multilateral channels tend to exist in the harmonization and enforcement realms, e.g., the World Trade Organization and the NAFTA, wherein considerable bilateral contact and conflict resolution occurs across a range of economic sectors. Other multilateral channels include the United Nations, the Organization of American States, the North Atlantic Treaty Organization, and the G8, among others (ibid. at 22).

Ibid. at 18 .

Ibid.

Mouafo, Morales \& Heynen, supra note 24 at 40-49.

For a visual representation, see ibid. at 40.

Ibid. at 43.

Memorandum of Understanding between the United States Department of Commerce's National Oceanic and Atmospheric Administration and Environment Canada Meteorological Service of Canada on Cooperation in Environmental Data Acquisition and Utilization (ibid. at 44). 
exploit, and archive data and information products derived from satellite observations. Officials meet in person or via teleconference and sit on a steering committee that meets annually.

Another functional area illustrative of the nature of these federal government networks is health. Health Canada engages in extensive cooperation via bilateral, multilateral, and informal channels with U.S. counterparts. Major cross-border health issues include access to and affordability of pharmaceuticals, health security, tobacco control measures, food and consumer goods safety, and human resources in the health sector. ${ }^{35}$ One transgovernmental network in this area is the Memorandum of Understanding (MOU) between the Centers for Disease Control and Prevention and the Population and Public Health Branch of Health Canada currently in effect. Pursuant to this MOU, the parties engage in ongoing collaboration in the area of cardiovascular disease prevention and heart health. Technical bilateral meetings at the senior level occur, as do technical exchanges and co-operation via expert committees and frequent conferences. In addition, parties engage in ongoing e-mail and telephone information exchanges. ${ }^{36}$ Another network is the Canada-U.S. MOU on First Nations and Inuit Health. This collaboration resulted in bilateral meetings between the Canadian First Nations and Indian Health Branch and the U.S. Indian Health Services Agency. In addition, ad hoc meetings, workshops, conferences, and information exchanges also defined the nature of the interaction. ${ }^{37}$

These examples offer snapshots of the complexity and sheer number of Canada-U.S. networks, however, we can ask: what are the implications? The Canadian government has identified three primary trends regarding the overlap and integration of these networks. First, foreign policy has been decentralized within and between governments, widening the circle of international affairs participants. As a result, foreign policy-making is more complex and less susceptible to central coordination. ${ }^{38}$ Second, technical expertise has become more important in the context of foreign relations, which cannot reside within a single ministry. Many domestic departments now partake in international relations. ${ }^{39}$ Third, and related, most domestic departments have established international bureaus or divisions to manage and coordinate a growing portfolio of international activities. ${ }^{40}$ Thus, it is these linkages, which take place outside of formal treaties and diplomatic channels, that serve as the defining feature of the Canada-U.S. relationship. This then, confirms what Slaughter aptly described — networks at the Canada-U.S. federal level have a strong hand in shaping the bilateral relationship and, by extension, North American governance.

\section{IV. “All Politics is Local”}

At first blush, Slaughter's concept of the disaggregated state is certainly applicable to the Canada-U.S. relationship. The myriad of horizontal linkages that exist between the federal governments of Canada and the U.S. are prototypical examples that buttress the

Mouafo, Morales \& Heynen, ibid. at 70.

Ibid. at 71.

For a visual representation, see ibid.

Heynen \& Higginbotham, supra note 24 at 16.

Ibid. at 17.

Ibid. 
disaggregated state framework. However, it is also testament to the invisibility of subnational governmental entities to international lawyers. ${ }^{41}$ If we pick up our magnifying glass and examine Canada-U.S. transgovernmental networks a bit more closely, something striking becomes apparent: these networks transcend the federal government level and penetrate deeply into every Canadian province and many U.S. states. The para-diplomacy ${ }^{42}$ conducted by provinces and states is due to a number of factors, the most significant of which is the fact that 96 percent of the Canadian population lives in the seven provinces that share a border with the U.S. ${ }^{43}$

In their relations with U.S. counterparts, Canadian vertical transgovernmental networks include officials at the federal, state, and sometimes regional and local levels. Examples illustrating this point include (1) the CANAMEX Coalition, a north/south intermodal trade and transportation corridor from northern Alberta to the Pacific Coast of Mexico. Meetings are held quarterly, at which representatives from state and provincial governments, as well as officials from the Canadian Consulate in Los Angeles, attend; (2) the Pacific Salmon Commission, which meets four times annually and draws representatives from British Columbia and the Department of Fisheries and Oceans Canada, among others; (3) International Mobility and Trade Corridor, a network that includes members such as Transport Canada, the British Columbia Ministry of Transportation, Greater Vancouver Regional District, and Whatcom County, Washington State; (4) the Cross-Border Crime Forum, which is a consultative forum established in 1997 at the federal government level but which includes participation by provinces (such as British Columbia) and states; (5) Team Canada Atlantic, a partnership between U.S. entities and Canadian federal agencies, such as Foreign Affairs Canada, International Trade Canada, Agriculture and Agri-Food Canada and the governments of Prince Edward Island, Nova Scotia, New Brunswick, and Newfoundland and Labrador, that aims at strengthening the trade and investment relationship between Atlantic Canada and the U.S.; (6) the Provinces/States Advisory Group, an advisory forum to the federal Canada-U.S. Consultative Committee on Agriculture that meets annually and includes Agriculture and Agri-Food Canada as a key collaborator; and (7) the Transportation Border Working Group, which includes Federal Departments such as Transport, Foreign Affairs and International Trade, as well as provincial governments including Nova Scotia. ${ }^{44}$

Provincial and territorial governments also engage horizontally with states without federal government involvement and are structured according to multi-state and multisectoral channels; multi-state and sector specific channels; and bilateral channels. ${ }^{45}$ Significantly, the most common issues tackled in a state multilateral forum are related to the economy and environment. For example, Alberta, British Columbia, and Saskatchewan are members of the

41

42

For a discussion of this invisibility as it relates to cities, see Gerald E. Frug \& David J. Barron, "International Local Government Law” (2006) 38 The Urban Lawyer 1.

Para-diplomacy refers to foreign policy-making that takes place among sub-state actors, such as states and provinces: see Richard Vengroff \& Jason Rich, “Paradiplomacy and the Canadian Provinces” (Paper presented at the annual meeting of the American Political Science Association, 2004), online: APSA <http://convention2.allacademic.com/one/apsa/apsa04/>; David Romano, "Para-Diplomacy: The Case of the Iraqi Kurds” (Paper presented at the annual meeting of the International Studies Association, Montreal, 2004), online: ISA <http://convention2.allacademic.com/one/isa/iso06/>. Heynen \& Higginbotham, supra note 24 at 36. Mouafo, Morales \& Heynen, supra note 24 at 158, 163, 172, 187, 193. Heynen \& Higginbotham, supra note 24 at 36. 
Rocky Mountain Trade Corridor, an ongoing collaboration with states in the Rocky Mountain region. These states and provinces interact by attending an annual conference and cross-border trade seminars three times a year. ${ }^{46}$ Another example is the Annual Conference of New England Governors and Eastern Canadian Premiers, which Prince Edward Island (among other eastern provinces) engages in by attending an annual conference and multilateral meetings of governors and premiers. This network also maintains ongoing working collaboration via three committees: trade and globalization, the environment, and energy. ${ }^{47}$ Ontario, too, engages in a broad array of state-provincial linkages. This should come as no surprise, given that it serves as the economic engine of Canada and borders manufacturing states like Minnesota, New York, Ohio, Michigan, and Pennsylvania (through the Great Lakes). For example, one particularly interesting network is the exchange of information, consultations, ad hoc meetings, and regular contact that occurs between the New York State Exchange and the Ontario Securities Commission. ${ }^{48}$ Ontario also participates in the Council of State Governments, the National Governors' Association, and the Council of Great Lakes Governors. It also is a member of the Great Lakes Regional Forum on Agriculture and the Great Lakes Commission, the latter of which meets biannually to discuss water quality and quantity for the Great Lakes region. With respect to Canadian territories, the Northwest Territories, for example, has limited formal relations with the U.S. However, relations are administered through various departments, such as Intergovernmental Affairs, the Department of Justice, Department of Resources, and Wildlife and Economic Development by participation in events such as the Western Governors' Association, the Council of Western Attorneys General, and the Interior West Fire Council, respectively. ${ }^{49}$

With respect to bilateral information linkages, environmental issues seem to dominate, with British Columbia and Manitoba engaging in the most networks in this functional area. British Columbia, for example, has co-operation agreements, or general “arrangements,” with the States of Washington, Idaho, and Montana, each of which entails meeting counterparts to discuss issues of import. ${ }^{50}$ Manitoba's engagement in this area primarily focuses on formal MOUs with Minnesota, North Dakota, South Dakota, and even Missouri, each of which concerns water-related issues. ${ }^{51}$

Finally, evidence suggests that multilateral information transgovernmental networks penetrate past the state-provincial level, down to regional and local government levels. ${ }^{52}$ These networks include the Buffalo-Fort Erie Public Bridge Authority (with representatives from federal, state-provincial, and local governments), the International Association of Great Lakes and St. Lawrence Mayors, Niagara Region Cross-Border Mayors, and the Niagara 10, a network of officials from the ten municipalities bordering the Niagara River. These networks tend to be multilateral, with few bilateral arrangements documented. This may have

\footnotetext{
$46 \quad$ Mouafo, Morales \& Heynen, supra note 24 at 159.

$47 \quad$ Ibid. at 199.

$48 \quad$ Ibid. at 196

$49 \quad$ Ibid. at 180,182

$50 \quad$ Ibid. at 164.

$51 \quad$ Ibid. at 169. Specifically, Manitoba signed the Minnesota-Manitoba Water Resources Protection MOU (2001); the Flood Mitigation Co-operation on the Red River between Minnesota, North Dakota, South Dakota, and Manitoba MOU (2004); and the Missouri-Manitoba Water Transfers MOU (2001).

52 See Kathryn Bryk Friedman \& Deborah L. VanNijnatten, “Constructing the Great Lakes Border Region:
} A Two-Pronged Approach” Journal of Borderland Studies [forthcoming]. 
to do with the fact that there is "power in numbers," that is, several local governments uniting across the border will have more political clout than a single municipality.

In the end, these Canada-U.S. networks, among hundreds of others, represent the day-today reality that defines the Canada-U.S. relationship. Thus, notwithstanding the fact that more than 300 treaties are in force between Canada and the U.S., transgovernmental networks serve as important drivers of the bilateral relationship, facilitating understanding, collaboration, and contact. ${ }^{53}$

\section{BEYOND TRANSGOVERNMENTAL NETWORKS?}

In focusing on transgovernmental networks, Slaughter does not discount the importance of non-governmental actors or the private sector. Rather, she suggests that " $[\mathrm{u}]$ sing government networks as the spine of broader policy networks, including international organizations, NGOs, corporations, and other interested actors, [can guarantee] wider participation in government network activities [while] also retaining an accountable core of government officials." 54 According to Slaughter, this mutation is critical to securing accountability.

In the context of the Canadian-U.S. relationship, we witness a constellation of publicprivate or public non-governmental organization (NGO) networks among states and provinces all along the 49th parallel. These networks encompass diverse issue areas such as regional economic development, security, and the environment. The most highly developed and significant is the Pacific Northwest Economic Region (PNWER). A public-private partnership, PNWER was established in 1991 by statute in the organization' s original seven legislative jurisdictions - Washington, Oregon, Idaho, Montana, and Alaska in the U.S., and British Columbia and Alberta in Canada. Canada's Yukon Territory joined PNWER in 1994. In 2008, the PNWER Executive Board voted in favour of Saskatchewan joining, and in 2009, it voted to admit the Northwest Territories into PNWER as well.

The public sector was the driving force behind the establishment of PNWER. Since its inception, all state and provincial legislators were members, with governors and premiers added to the PNWER governance structure in 1993. However, in 1994, PNWER incorporated official private sector participation, including the non-elected public sector, non-profit organizations, and NGOs. PNWER’s 2006 annual budget was US\$900,000, with approximately one third coming from state and provincial dues, one third from private sector sponsorship and dues, and one third from public and private grants. ${ }^{55}$

Currently, PNWER serves to facilitate co-operation and coordination and promote communication between the public and private sectors within these jurisdictions. Specifically, PNWER's mission is fourfold: to promote greater regional collaboration; enhance the competitiveness of the region in both domestic and international markets; 
leverage regional influence in Ottawa and Washington, D.C.; and achieve continued economic growth while maintaining the region's natural environment. ${ }^{56}$

PNWER has an elaborate governance structure that is modelled upon balanced representation. Its organs include an Executive Committee; ${ }^{57}$ Delegate Council; ${ }^{58}$ Private Sector Council (PSC); ${ }^{59}$ Private Sector Board of Directors; ${ }^{60}$ Secretariat; ${ }^{61}$ and Working Groups. ${ }^{62}$ In addition to balance, PNWER is keenly aware of national sovereignty, with all decisions of the Executive Committee made by consensus. ${ }^{63}$

Ibid.

57 The PNWER Executive Committee consists of one legislator from each PNWER jurisdiction, one private sector board member chair from each jurisdiction, four governors/premiers (or their designee), and the PNWER Executive Director. This includes the PNWER president and first and second vicepresidents, whom, according to PNWER statutes, must be elected legislators. The private sector board members and the executive director were added in 1999 to the Executive Committee as ex-officio members of the Executive Committee (ibid.).

58 The Delegate Council is the founding entity of PNWER. The Delegate Council consists of the governors/premiers (or their representatives) from each of the state/provinces, as well as four legislators (and four alternates) from each state/province. The Delegate Council is encouraged to hold meetings of the delegates and alternates within each jurisdiction to discuss implementing legislative policy forwarded by PNWER working groups. The Delegate Council is responsible for coordinating the agendas from the public sectors of each jurisdiction, promoting participation in each working group, as well as ensuring that the PNWER organization continues to adhere to its original mission and regulations as outlined in PNWER's founding statutes. The Delegate Council encourages bilateral and regional interaction between legislative members. The Council is, by design, bipartisan, and Delegate Council members are chosen by all four party caucuses in the states, and the Canadian provinces are encouraged to include opposition party delegates in their delegations (ibid.).

59 Every PNWER private sector member sits on the PSC; this includes business, the non-elective public sector, NGOs, and other non-profit organizations. Each state/provincial delegation within the PSC selects four members from its jurisdiction to sit on the Private Sector Board of Directors. Each jurisdiction then selects one of their four to serve as the chair of their private sector jurisdiction, and the chair will then sit on the Executive Committee. In addition, from among the chairs of each jurisdiction, one is selected via consensus of the PSC to serve as PSC Chair. The PSC Chair may then appoint any PSC vice-chairs from the board members as needed. The purpose of the PSC is to provide a forum for the private sector to meet and discuss issues of concern, and communicate these through the working groups and the Private Sector Board of Directors to the PNWER Executive Committee. Furthermore, each state/province delegation is encouraged to hold meetings as needed in their own jurisdiction and promote business leadership within all aspects of PNWER (ibid.).

60 The Private Sector Board of Directors is made up of four members from each state/provincial jurisdiction as selected within the PSC (process described above). The board is responsible for administering the concerns of the PSC developing action plans as to how these concerns can be addressed and resolved, and recruiting new PSC members. In addition, the board is responsible for ensuring and promoting private sector participation in each working group, and developing activities that provide deliverables for PSC membership (ibid.).

61 The PNWER Secretariat manages the PNWER organization from its office in Seattle, Washington. It consists of an executive director, program managers who oversee specific working groups, and other support staff. The Secretariat is the administrative arm for the president, vice-presidents, and the Executive Committee, and serves as the fiscal manager for the PNWER organization. Among its responsibilities are to coordinate communication among all PNWER divisions and assist them in their various activities (ibid.).

62 The Working Groups include the following areas: 2010 Winter Olympics/Tourism; agriculture; border issues; energy I and II; environment; forestry; health care; high tech; homeland security; invasive species; sustainable development; telecommunications; trade and economic development; transportation; water policy; and workforce development (ibid.).

63 Abgrall, supra note 22 at 9. 
PNWER exerts its influence in policy circles in a number of ways. In addition to lobbying, ${ }^{64}$ PNWER promotes partnerships between various levels of governments ${ }^{65}$ and facilitates meetings to exchange information. ${ }^{66}$

Turning toward the eastern seaboard, the Gulf of Maine Council on the Marine Environment was established in 1989 to "maintain and enhance environmental quality in the Gulf of Maine to allow for sustainable resource use by existing and future generations." 67 Membership is comprised of the governors and premiers of Massachusetts, New Hampshire, Maine, New Brunswick, and Nova Scotia, along with federal agencies, NGOs, and private sector participants. The Council consists of five committees: Management Committee; Habitat Committee; Environmental Quality Monitoring Committee; Public Education and Participation Committee; and the Data Information and Management Committee. The Council also has a Secretariat that rotates among jurisdictions. By most accounts, the Council has greatly contributed to improving the environmental situation in the Gulf of Maine by publishing a number of scientific studies and providing advice on the management of the Gulf's resources. ${ }^{68}$

One final example of a public-private network is the Great Plains Institute. Launched in 1997, this institute is an association of public and private sector members from Iowa, Manitoba, Minnesota, North Dakota, South Dakota, and Wisconsin that are charged with collectively solving the most pressing contemporary energy issues in the region. The institute has a small permanent staff and a board of governors of approximately ten members. It concentrates on energy security and bio-based material. Specifically, it has six programs: Advance Coal with Carbon Capture; Upper Midwest Hydrogen Initiative; Powering the Plains; Policy and Technology Delegations; Efficiency and Conservation; and Next Generation Biomass Energy. The Great Plains Institute has been very influential at policymaking in this area. For example, in June 2007, after four years of consultation with diverse and sometimes opposed interests, it released "Powering the Plains," a consensus driven approach to energy independence in the midwest. This document served as the roadmap for eight midwestern governors and the premier of Manitoba to sign an agreement that established goals and initiatives to increase energy security, efficiency, and alternatives to reduce greenhouse gas emissions. Additionally the institute's Advance Coal program has received national attention. ${ }^{69}$ It is evident, then, that Canada-U.S. networks at the sub-federal level among various stakeholders — public, private and non-profit — play a critical role in policy-making in North America.

PNWER is a strong advocate when it comes to the harmonization of regulations in energy, transportation, agriculture, and the environment. It also encourages the harmonization of infrastructure (see ibid. at 10).

For example, in 2000, PNWER invited the federal governments, the state/provincial governments, and the local governments to finance operations of a bilateral commission on rail transportation. In 2001, it urged all levels of government to communicate and collaborate on animal health emergency management (ibid.).

66 For example, in 2003, PNWER was instrumental in organizing a meeting of the Department of Homeland Security Oversight Committee, at which time officials from Canada and British Columbia had the opportunity to discuss border issues with U.S. officials (ibid.).

67 Online: Gulf of Maine Council on the Marine Environment <http://www.gulfofmaine.org>.

68 Abgrall, supra note 22 at 22.

69 Neal St. Anthony, “Nonprofit has Big Voice on Power" Star Tribune (7 January 2008), online: StarTribune <http://www.startribune.com/business/13514456.html>. 


\section{THROUGH THE LOOKING GLASS}

In Lewis Carroll's famous works, ${ }^{70}$ Alice, the main character, enters a world that is upside down, and one that, at times, seems absurd. As the storylines unfold, however, an undeniable logic is revealed to the reader. Events and characters in Wonderland are not as strange as they seem at first glance. Alice's world through the looking glass serves as an apt metaphor for thinking of transgovernmental networks in North America and specifically those networks that exist between Canada and the U.S.

More research is needed to determine the relevance of these networks to North American governance. ${ }^{71}$ Nonetheless, this article raises three considerations for policy-makers and scholars to consider when grappling with transgovernmental networks. First, Slaughter's concept of the disaggregated state, while useful, fails to capture the complex reality that drives the Canada-U.S. relationship. The concept of horizontal networks - networks that link counterpart officials across borders and function as information, enforcement, or harmonization networks - is certainly applicable to the North American context. Whether thinking of the collaboration between the Centers for Disease Control and Prevention and the Population and Public Health Branch of Health Canada in the area of cardiovascular disease, or problem solving by the Great Lakes Commission regarding water quality and quantity, empirical data collected by the Canadian government demonstrates that horizontal networks do indeed engage in information sharing, enforcement, and regulatory harmonization activities.

It is, however, also apparent that horizontal networks exist solely at the state, provincial, and local levels, and vertical networks do not merely exist between federal governments and supranational institutions. As this article demonstrates, these networks also exist between local, regional, state, provincial, and national officials. Whereas vertical networks, according to Slaughter's definition, are somewhat limited when thought of between nation-states and supranational organizations, they serve as powerful linkages when we drill down to examine networks below the federal government level. Thus, as Slaughter reprimands scholars for using a reified concept of the state, she, too, errs in that she does not envision an international order with networks below the national government level. Hence, her analysis does not adequately capture the complexity of sub-nation-state networks playing a part in international law. Slaughter's deep "conceptual shift" "72 therefore, is not deep enough, and should be modified to include sub-national actors.

Second, concerns that domestic agencies participating in transgovernmental networks lack democratic accountability and transparency have been well-documented. ${ }^{73}$ These concerns

$70 \quad$ Lewis Carroll, Alice's Adventures in Wonderland (New York: Sterling Juvenile, 2006); Lewis Carroll, Through the Looking-Glass and What Alice Found There (New York: Puffin Books, 1984).

71 For example, research documenting networks between the U.S. and Mexico, Canada and Mexico, and among all three parties would round out the picture portrayed in this article.

Slaughter, supra note 3 at 5.

See Joseph S. Nye, Jr., “Globalization’s Democratic Deficit” (2001) 80:4 Foreign Affairs 2; Kal Raustiala, “Sovereignty and Multilateralism” (2000) 1 Chicago J. Int'l L. 401; Anne-Marie Slaughter, “The Accountability of Government Networks” (2001) 8 Ind. J. Global Legal Stud. 347; Eric Stein, “International Integration and Democracy: No Love at First Sight”(2001) 95 A.J.I.L. 489; Anne-Marie Slaughter, "Agencies on the Loose? Holding Government Networks Accountable" in George A. 
range from the establishment of a global technocracy to lack of input in national and international policy-making. Underlying this line of thinking is the notion that domestic citizen participation, the cornerstone of national democratic authority, is severely limited or non-existent in international institutions and, more broadly speaking, the current international legal regime. ${ }^{74} \mathrm{New}$ forms of international co-operation have increasingly called for the transfer of rule-making authority to international institutions and regimes that lack openness and accountability. ${ }^{75}$ Thus, according to this view, the concentration of power in international institutions makes international law illegitimate. ${ }^{76}$

In pointedly addressing problems of accountability, Slaughter proposed that we reconceive the responsibilities of all national officials as including both a national and transgovernmental component so that they must all perform a dual function, which would necessitate making transgovernmental activity as visible as possible to legislators, interest groups, and ordinary citizens. ${ }^{77}$ Slaughter also argues that public-private networks offer a modicum of accountability in that they are held together by the "spine” of government actors, thus assuring a more democratic process. ${ }^{78}$

Examining transgovernmental networks in the North American context raises real questions about the validity of these prescriptions and fleshes out nuances associated with democratic theory and accountability. On the one hand, it is arguable that transgovernmental networks in North America are more democratic because of their decentralized nature. Hundreds upon hundreds of individuals from the public, private, and NGO sectors seemingly participate in Canada-U.S. policy-making. The establishment and use of transgovernmental networks in international law, then, seems to tackle head-on the strongest accountability and transparency critique of international law, that is, the clubby nature of international institutions and limited participation by non-governmental representatives. Truly, then, one could argue that North American policy-making illustrates more involvement of people in

Bermann, Matthias Herdegen \& Peter L. Lindseth, eds., Transatlantic Regulatory Co-operation: Legal Problems and Political Prospects (New York: Oxford University Press, 2000). For an alternative perspective contradicting the notion that a democratic deficit exists in international law, see Ruth W. Grant \& Robert O. Keohane, “Accountability and Abuses of Power in World Politics” (2005) 99 American Political Science Review 29.

74 For discussion of the democratic deficit and associated concepts using an international administrative law lens, see Benedict Kingsbury, Nico Krisch \& Richard B. Stewart, “The Emergence of Global Administrative Law” (2005) 68:3 Law \& Contemp. Probs. 15. See also José E. Alvarez, “Introducing the Themes" (2007) 38 V.U.W.L.R. 159 at 159-160:

As a number of the contributors [to this special volume] point out, the most common definition of democracy focuses on governance through elected representatives, or majority rule. Accordingly, the most common "democratic" complaint lodged against international law-making processes is that since there is no international parliament subject to proportional representation of the peoples of the world, international law-makers lack the ties to democratically elected politics that legitimise

law within democracies.

For a good discussion of how the democratic deficit plays out in five distinct ways in customary or "raw” international law, see John O. McGinnis, "The Comparative Disadvantage of Customary International Law” (2006) 30 Harv. J.L. \& Pub. Pol’y 7 at 9-11. 
the process at a localized level, and, hence is more democratic, at least as Alexis de Tocqueville defined the term. ${ }^{79}$

We, however, still cannot escape fully from fundamental concerns regarding accountability and transparency. With so many more actors engaged in the process than previously accounted for, who is in charge? Who does the average citizen go to in providing input on a particular issue such as the environment out west - PNWER? British Columbia? The State of Washington? Environment Canada? The EPA? A private sector representative? Should entities like the Gulf of Maine Council and the Great Plains Institute have an obligation, or be mandated, to include on their boards every conceivable interest affected in their areas of expertise? Should distinctions exist between obligations of "pure" transgovernmental networks versus those that encompass public and private or NGO actors ${ }^{80}$ The decentralized nature of Canada-U.S. collaboration actually hones issues associated with accountability and brings new ones to light — particularly those associated with weakening of the chain of command.

Third and finally, the striking presence of transgovernmental networks in North America has implications for the international legal path to further North American integration. Most would agree that the level of economic integration among Canada, Mexico, and the U.S. has reached a point where a new governance framework is required to further shape the contours of North American competitiveness. To paraphrase Jane Jacobs, North America generates the wealth of Canada, the U.S., and Mexico, however, its governance has not kept up with this reality. ${ }^{81}$ This article confirms that transgovernmental networks are the defining feature of Canada-U.S. relations. Therefore, they should at least be part of the calculus used to devise a North American governance structure that enhances economic competitiveness. This, however, raises interesting questions regarding transgovernmental networks as sources of international law. ${ }^{82}$ In the absence of any formalized rule-making, any notion of acquis communautaire $^{83}$ is difficult. More pertinent, however, are questions concerning customary international law. The Statute of the International Court of Justice defines the sources of international law as including "international custom, as evidence of a general practice accepted as law." 84 Article 38(1)(b) specifically emphasizes that the two requirements of customary law are state practice plus "opinio juris sive necessitatis," or acceptance of the practice as obligatory. The process by which customary international law is established takes

Alexis de Tocqueville, Democracy in America (London: Longmans Green, 1875) vol. 1.

Many thanks to an anonymous reviewer for raising this point.

Jane Jacobs, Dark Age Ahead (New York: Random House, 2004) at 3-26.

See Anne-Marie Slaughter, Andrew S. Tulumello \& Stepan Wood, “International Law and International Relations Theory: A New Generation of Interdisciplinary Scholarship” (1998) 92 A.J.I.L. 367 at 390. Acquis communautaire is a basic European principle that has become a vital concept in European Union law. Acquis communautaire essentially conveys the idea that the institutional structure, scope, policies, and rules of the Union are to be treated as "given" (acquis), not to be called into question or substantially modified by new states at the time they enter. This principle is now found in Article B of the Treaty on European Union, 7 February 1992, 1759 U.N.T.S. 3, which describes one of the Union objectives as "to maintain in full the 'acquis communautaire’ and build on it.” See Roger J. Goebel, “The European Union Grows: The Constitutional Impact of the Accession of Austria, Finland and Sweden” (1995) 18 Fordham Int'l L.J. 1092 at 1095-97, 1140-57.

Statute of the International Court of Justice, 26 June 1945, Can. T.S. 1945 No. 7, art. 38(1)(b). 
place over many years, and is often "aided by the adoption of resolutions, declarations and treaties that articulate the new rules.”,85

It is too early to tell if transgovernmental networks that define the Canada-U.S. relationship have in fact devolved into customary law, as it is not clear at all whether agency officials consider their various meetings and commitments as obligatory. Nonetheless, what is clear is that these networks can serve as tools of statecraft in and of themselves. Although it is certainly plausible that these networks may lead to a new treaty or agreement for North America, it is as likely that they may supplement, or gradually replace, traditional international governance mechanisms such as the NAFTA.$^{86}$ Although seemingly absurd, this notion, as Alice's adventures suggest, can serve in the end as a logical alternative blueprint for North American governance. 